\title{
IDENTIFICATION OF CHEMICAL COMPOUNDS FROM KARAMUNTING STEM (Rhodomyrtus tomentosa) BY THIN LAYER CHROMATOGRAPHY
}

\section{Agustinawati Umaternate}

Universitas Muhammadiyah

Palangkaraya, Palangka Raya, Central

Kalimantan, Indonesia

email: dwisuparna@gmail.com

\section{Keywords:}

Chemical Compounds

Karamunting

$T L C$

\begin{abstract}
Karamunting or Kalimantan Grapes (Rhodomyrtus tomentosa) is a medicinal plant from Central Kalimantan that is easily found in shrubs. Based on hereditary experiences of the people of Central Kalimantan, karamunting can be used for the treatment of various diseases, one of which is diabetes. This study aims to identify the chemical compounds contained in the karamunting stem. The method used is thin layer chromatography with eluent $n$-hexane : ethyl acetate and methanol : chloroform. Besides, a color reaction was carried out to determine the group of compounds contained in the methanol extract of the karamunting stem. The TLC results show better stain separation in eluent n-hexane : ethyl acetate with the formation of four stains. Positive results are indicated by the content of phenol, saponin, flavonoid and terpenoid compounds. The existence of this group of compounds can be a clue to further research on the truth of the efficacy of karamunting.
\end{abstract}

\section{INTRODUCTION}

The community uses many alternative treatments for diabetes besides using drugs from doctors. Traditional medicines from plants that can be useful drugs that are often used based on hereditary experiences. Karamunting or Kalimantan grapes (Rhodomyrtus tomentosa) is a wild plant that is easily found in shrubs (Santic et al., 2017). Karamunting is known to have various properties from empirical use. The plant parts used are leaves, stems, roots or mixtures of the three parts (Vo \& Ngo, 2019).

This Karamunting fruit sweet taste can be eaten and made jam. In addition, in Malaysia the leaves of Karamunting are empirically used as a medicine for diarrhea and dysentery, and function as a protective drug after birth (Salni et al., 2002). In Indonesia, the leaves of this plant are used to cover wounds. The stem can act as a black dye and has been used to blacken the eyebrows and teeth (Hamid et al., 2017). Besides, in Thailand this plant is also used as an anti-infective drug caused by various types of bacteria (Saising et al., 2008). In addition, it is also used as an ornamental plant. On the islands of Java and Florida, these shrubs are planted in gardens, because the aesthetic value of shrubs and flowers is highly valued (Liu \& Guo, 2012). Empirically, as much as $60 \mathrm{~g}$ of Karamunting plants are boiled with 3 cups of water until I cup is left, after which it is filtered and cooled and then drunk until it is finished, carried out routinely can reduce blood sugar levels. Based on ancestral experiences in the community, Central Kalimantan this plant is used for the treatment of diabetes (Kartini \& Dewi, 2013).

Preliminary examination of Karamunting leaves shows the presence of flavonoid compounds, steroids, triterpenoids, tannins, catholic tannins, quinones and sodium, calcium, potassium and magnesium elements. From $95 \%$ ethanol extract, flavonoid group which was suspected to be mirisetin was isolated in the form of glycosides, and phenolic acid groups were suspected to be $\mathrm{p}$-hydroxybenzoic acid and p-kumarat acid in the form of esters (Rosli et al., 2017).

However, it is not yet known what active chemical compounds are contained in the Karamunting stem. Thus it is necessary to do research on the active chemical compounds contained in the Karamunting stem. This study aims to determine the content of active chemical compounds found in the Karamunting stem. The method used is thin layer chromatography by 
using several types of eluent mixtures. In addition, a proximate analysis is also performed to determine the types of metabolites contained in the Karamunting stem.

\section{MATERIAL AND METHODS}

\section{Tools and Materials}

The main material used in the study is Karamunting stem to be extracted and identified as the active ingredient. This plant was taken from the city of Palangka Raya, Central Kalimantan. Other materials used were methanol, purified water, antimony (III) chloride, acetate anhydrous acid, hydrochloric acid, sulfuric acid, iron (III) chloride ethyl acetate, flouroglusin, chloral hydrate, chloroform, methanol, nButanol, n-Hexan, and Petroleum eter. The tools used are cup cups, measuring cups, condensers and round bottom flasks, erlenmeyer flasks, ultra violet lamps, refrigerators, electric waterbaths, rotary evaporator, analytical scales, and a set of TLC tools.

\section{Methods}

\section{Sample Preparation}

Karamunting stems that have been collected and cleaned, then dried by aerating in a place that is not subject to direct sunlight, then mashed until smooth and dried.

\section{Proximate Analysis}

Determination of the proximate content of stem Karamunting is part of the preliminary research stage, carried out to determine the characteristics of Karamunting stem powder, which includes water content, fat content, fiber content, protein content, ash content, and carbohydrate content (Achi et al., 2017). Each analysis was replicated three times to obtain convincing results.

\section{Examination of phenols}

Put $0.5 \mathrm{~g}$ of the sample Karamunting stem powder into the test tube, add $5 \mathrm{ml}$ of distilled water, then heat it to boil for 2 minutes, cool and strain, the filtrate obtained is put into the test tube plus I\% iron (III) chloride solution will formed green blue or greenish black indicates the presence of phenol.

\section{Examination of alkaloids}

Inserted $0.5 \mathrm{~g}$ of sample Karamunting into the test tube, added I $\mathrm{ml}$ of $2 \mathrm{~N} \mathrm{HCl}$ and $9 \mathrm{ml}$ of distilled water, then heated to boiling for 2 minutes, then moved the obtained filtrate into three different test tubes. In the first test tube 2 drops of LP mayer solution were added, in the second test tube, 2 drops of Bouchardat LP were added, and in the third test tube, 2 drops of Dragendorff LP solution were added. Yellow deposits or white deposits in the first test tube are formed, brown yellow deposits in the second test tube and red brown deposits in the third test tube, indicating the presence of alkaloids.

\section{Examination of saponin}

Karamunting stem powder is put into a tube, reaction as much as $0.5 \mathrm{~g}$, add $10 \mathrm{ml}$ of hot water, cool and shake hard for 10 seconds. A stable froth is formed for no less than 10 minutes, foam is $1-10 \mathrm{~cm}$ high. In addition to 2 $\mathrm{N}$ hydrochloric acid the foam was not lost, indicating the presence of saponin groups.

\section{Examination of flavonoids}

Put the Karamunting stem into the reaction tube, react as much as $0.5 \mathrm{~g}$, add $10 \mathrm{ml}$ of water, then heat it to boil, then the extract obtained is added with Mg metal powder and a few drops of concentrated $\mathrm{HCl}$. The formation of orange to red indicates the presence of flavonoids.

\section{Examination of terpenoids}

Put $0.5 \mathrm{~g}$ of the sample caramunting stem into a cup of glass, add $5 \mathrm{ml}$ of chloroform, then heat it over watering, then cool it. Chloroform extract obtained is put into the drops of the hole as much as 3 drops and left to dry. Then added drop by drop of concentrated sulfuric acid. A red or red purple color indicates a terpenoid. 


\section{Extraction}

Optimization of stem extraction process Karamunting is part of basic research which will later be used in the treatment of isolation and identification of groups of secondary metabolic compounds. The extraction process aims to separate dissolved components from non-dissolved components by dissolving the material into a suitable solvent. Selection of solvents according to the nature of the polarity of the substance to be drawn. The solvent used can be a polar solvent artist or a non-polar solvent, so that the component forming the material is dissolved in the solvent (Azwanida, 20I5).

Overall the research model was carried out on Karamunting stem by maceration method. Maseration was carried out by soaking $100 \mathrm{~g}$ of the sample in 400 $\mathrm{ml}$ of methanol and three times variations, three, six, and nine days, were carried out. Factors that affect quantitatively the extract yield obtained can be determined at the time the observation was made. The extract results with the best yield will be used in the next research process.

Identification of Chemical Compounds with TLC

The thick extract and comparison standard are bottled on the TLC plate separately, then eluted to the suitable eluent. The study was conducted on caramunting stem about secondary metabolites which can be used as raw material for medicine. The combination of eluents used was methanol : chloroform 3 : I and n-hexane : ethyl acetate $9: 1$.

\section{RESULTS AND DISCUSSION}

\section{Proximate Analysis}

Determination of the proximate content of the Karamunting stem used in this study is the preliminary research stage which is expected to obtain information on the characteristics of Karamunting stem powder which includes moisture content, fat content, fiber content, ash content, protein and carbohydrates contained in the Karamunting stem powder as shown in Figure I.

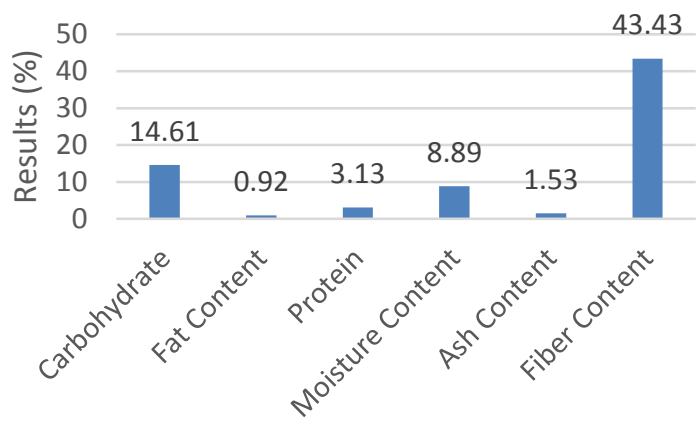

Figure I. Proximate test results of the Karamunting stem

Determination of Secondary Metabolite Compounds Determination of secondary metabolites is done to determine the chemical content in plants, consisting of phenol compounds, alkaloids, saponins, steroids, flavonoids, and terpenoids, as shown in Table I.

Table I. Results of examination of secondary metabolites of Karamunting stem powder

\begin{tabular}{|c|c|c|c|c|c|}
\hline \multirow[b]{2}{*}{ No } & \multirow[b]{2}{*}{ Compounds } & \multirow[b]{2}{*}{ Reagent } & \multicolumn{2}{|c|}{ Results } & \multirow[b]{2}{*}{ Conclusion } \\
\hline & & & $\begin{array}{l}\begin{array}{l}\text { Positive- } \\
\text { value }\end{array} \\
\end{array}$ & Acquired & \\
\hline 1 & Phenols & $\begin{array}{l}\text { Iron (III) } \\
\text { chloride }\end{array}$ & $\begin{array}{l}\text { Green, } \\
\text { blue I } \\
\text { greenish } \\
\text { black }\end{array}$ & Black green & Positive \\
\hline \multirow[t]{3}{*}{2.} & Alkaloids & Mayer & $\begin{array}{l}\text { Yellow / } \\
\text { brown } \\
\text { precipitate }\end{array}$ & $\begin{array}{l}\text { No deposits } \\
\& \text { changes } \\
\text { occur } \\
\text { Color }\end{array}$ & Negative \\
\hline & & Dragendorf & $\begin{array}{l}\text { Yellow / } \\
\text { brown } \\
\text { precipitate }\end{array}$ & $\begin{array}{l}\text { No deposits } \\
\text { occur }\end{array}$ & Negative \\
\hline & & Bouchardat & $\begin{array}{l}\text { Chocolate } \\
\text { deposits }\end{array}$ & $\begin{array}{l}\text { No deposits } \\
\text { occur }\end{array}$ & Negative \\
\hline 3. & Saponin & $\begin{array}{l}\text { Hot water, } \\
2 \mathrm{~N} \mathrm{HCl}\end{array}$ & $\begin{array}{l}\text { Foam as } \\
\text { high as } \\
1-10 \mathrm{~cm}\end{array}$ & $\begin{array}{l}\text { Foam as high } \\
\text { as } 8 \mathrm{~cm}\end{array}$ & Positive \\
\hline 4. & Steroids & $\begin{array}{l}\text { Lieberman } \\
\text { bourchard }\end{array}$ & $\begin{array}{l}\text { Red / } \\
\text { purple } \\
\text { Changed } \\
\text { to blue, } \\
\text { purple red }\end{array}$ & $\begin{array}{l}\text { There is no } \\
\text { change }\end{array}$ & Negative \\
\hline \multirow[t]{2}{*}{5.} & Flavanoids & Amyl Alcohol & $\begin{array}{l}\text { Chocolate } \\
\text { deposits in } \\
\text { the Amyl } \\
\text { alcohol } \\
\text { layer }\end{array}$ & $\begin{array}{l}\text { brown } \\
\text { deposits and } \\
\text { discoloration }\end{array}$ & Positive \\
\hline & & $\begin{array}{l}\mathrm{Mg} \text { powder } \\
\text { and } \mathrm{HCl} \\
\text { Concentrated }\end{array}$ & $\begin{array}{l}\text { It is } \\
\text { formed in } \\
\text { orange red }\end{array}$ & $\begin{array}{l}\text { Orange - } \\
\text { red is } \\
\text { formed }\end{array}$ & Positive \\
\hline 6. & Terpenoids & $\begin{array}{l}\text { Concentrated } \\
\text { sulfuric acid }\end{array}$ & $\begin{array}{l}\text { Purplish } \\
\text { red color } \\
\text { is formed }\end{array}$ & $\begin{array}{l}\text { Purplish red } \\
\text { color is } \\
\text { formed }\end{array}$ & Positive \\
\hline
\end{tabular}

Identification of Chemical Compounds with TLC

Methanol extract extracted from caramunting stem was dried / concentrated with a vacuum rotary evaporator 
and produced concentrated extracts of $10.12 \mathrm{~g}$, suspended with methanol : chloroform (3: I), then analyzed by thin layer chromatography (TLC) using $n$ hexane : ethyl acetate $(9: 1)$ and analyzed under the UV-360 nm lamp, there are four purple stains with each Rf; $0.23 ; 0.4 I ; 0.53$; and 0.66 . KLT results are shown in Figures 2.

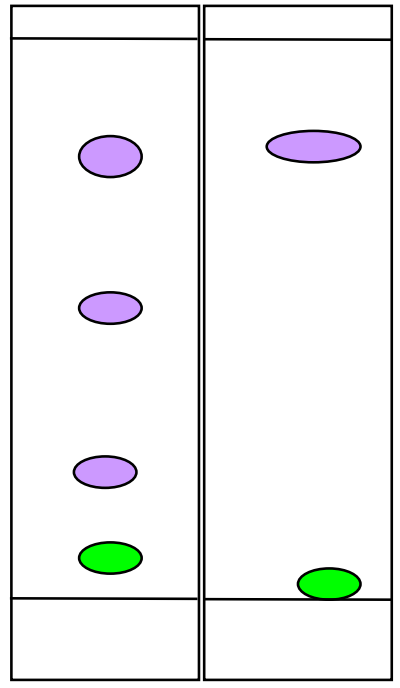

(a)

(b)

Figure 2. Results of TLC extract of methanol in (a) nhexane : ethyl acetate (9: I) and (b) methanol : chloroform (3: I) using UV nodes $254 \mathrm{~nm}$

\section{CONCLUSION}

Overall, this study has succeeded in showing the results of a fairly good separation of Karamunting stem methanol extract, which obtained positive results for the content of phenol, saponin, flavonoid and terpenoid compounds. The TLC results show better separation in the combination of non-polar eluent $n$-hexane: ethyl acetate, indicating the tendency of the properties of compounds contained in ethanol extract Karamunting is a non-polar compound. The presence of this group of compounds can be further researched on the truth of the efficacy of caramunting.

\section{REFERENCES}

Achi, N.K., Onyeabo, C., Ekeleme-Egedigwe, C.A., Onyeanula, J.C. 2017. Phytochemical, Proximate Analysis, Vitamin and Mineral Composition of Aqueous Extract of Ficus capensis leaves in South Eastern Nigeria. Journal of Applied Pharmaceutical Science. 7(3): $117-122$.

Azwanida, N.N. 2015. A Review on the Extraction Methods Use in Medicinal Plants, Principle, Strength and Limitation. Medicinal \& Aromatic Plants. 4(3): 1000196.

Hamid, H.A., Mutazah, R., Yusoff, M. 2017. Rhodomyrtus tomentosa: A phytochemical and pharmacological review. Asian Journal of Pharmaceutical and Clinical Research. I0(I):1016.

Kartini, N.H., Dewi, I.S. 2013. Identifikasi Keanekaragaman Hayati dan Pemetaan Bawah Tanah Kampus Terpadu Universitas Muhammadiyah Palangkaraya Sebagai Media Objek Pembelajaran. Anterior Jurnal. I 3(I):94105.

Liu, N., Guo, Q. 2012. Resource-use efficiencies of three indigenous tree species planted in resource islands created by shrubs: implications for reforestation of subtropical degraded shrublands. Plant Ecology. 21 3:1 177. II85.

Rosli, M.F.A., Asaruddin, M.R., Romli, A.M., Radhakrishnan, S.E., Nyawai, T.N., Ahmad, M.N. 2017. Phytochemical Studies of Rhodomyrtus tomentosa Leaves, Stem and Fruits as Antimicrobial and Antioxidant Agents. Transactions on Science and Technology. 4(3):396-40I

Saising, J., Hiranrat, A., Mahabusarakam, W., Ongsakul, M., Voravuthikunchai, S.P. 2008. Rhodomyrtone from Rhodomyrtus tomentosa (Aiton) Hassk. As a Natural Antibiotic for Staphylococcal Cutaneous Infections. Journal of Health Science. 54(5):589595.

Salni, D., Sargent, M.V., Skelton, B.W., Soediro, I., Sutisna, M., White, A.H., Sukandar, E.Y. 2002. Rhodomyrtone, an antibotic from Rhodomyrtus tomentosa. Australian Journal of Chemistry. 55(3):229-232.

Santic, Z., Pravdic, N., Bevanda, M., Galic, K. 20I7. The historical use of medicinal plants in traditional 
and scientific medicine. Psychiatria Danubina. 29(Suppl 4):787-792.

Vo, T.S., Ngo, D.H. 2019. The Health Beneficial Properties of Rhodomyrtus tomentosa as Potential Functional Food. Biomolecules. 9(2):76. 